IJIET, e-ISSN 2548-8430, p-ISSN 2548-8422, Vol. 2, No. 1, January 2018

International Journal of Indonesian Education and Teaching http://e-journal.usd.ac.id/index.php/IJIET

Sanata Dharma University, Yogyakarta, Indonesia

\title{
GROUP GUIDANCE SERVICES BASED ON FOLKLORE FOR STUDENTS JUNIOR HIGH SCHOOL
}

\author{
Agus Supriyanto \& Amien Wahyudi \\ Ahmad Dahlan University \\ agus.supriyanto@bk.uad.ac.id \& amien.wahyudi@bk.uad.ac.id \\ https://doi.org/10.24071/ijiet.v2i1.956
}

received 2 September 2017; revised 21 October 2017; accepted 2 December 2017

\begin{abstract}
Professional guidance and counseling services are based on a comprehensive guidance and counseling program. Professional counselors were able to implement the program of group guidance based assessment prior to program implementation with four competencies, (1) personality, (2) paedagogy, (3) social, and (4) professional. This article discusses the effectiveness of group guidance services through folklore. The fundamental goal of folklore as a medium of group guidance services is the history of the past can foster National Character. The research approach uses literature study. The analysis through descriptive analysis. The findings show that process of group guidance services through the opening stage, intermediate, core activities, and termination. Folklore as the primary basis of group guidance services carried out on the core activities. Folklore presented by thecounselor as a group leader and discussed by members with leader of the group to develop a National Character. Folklore in the process of group counseling is effective in order to grow a national character that corresponds to the origin of the formation of the Nation.
\end{abstract}

Keywords: group guidance, character, folklore method

\section{Introduction}

Each country has a diverse culture and unique character compared to other countries. Cultural diversity gives rise to unique features in every society of language, religion, ethnicity, race, color, and custom. Positive views on diversity give rise to a united nation with challenges in the era of globalization. Thenegative influence of cultural diversity that can affect all elements of the nation if the people of Indonesia can't appreciate all the differences of human diversity. School's role in developing the character of learners through the education of national character. Strengthening national character can be started from the optimization of character education based on local wisdom (Sultono \& Hilmi, 2015). Value-based education emphasizes the realization of good citizens, who possess holistic competencies in knowledge, skills, and traits based on the values of Pancasila or Five Principles of Indonesia or national character (Nurdin, 2015). 
The phenomenon behavior that does'not value differences between individuals can lead to anarchic behavior. The results revealed that tolerance tended to decline as national income inequality increased (Andersen \& Fetner, 2008). The anti-European attitude as a negative impact of globalization on people working in the profession threatens globalization and Europeisation tends to become more intolerant towards immigrants and foreign workers (Giugni \& Morariu, 2010). The Wahid Institute's report on violations of freedom of religion and belief and intolerance in Indonesia in 2013 which reached 245 events and in 2014 reached 154 events or down 40 percent with 55 cases of events that is Yogyakarta Special Region with 21 events, North Sumatra with 18 events, DKI Jakarta with 14 events, Central Java with 10 events, and South Sulawesi with 10 events (Setiawan, 2015). The results revealed that Sunni and Shias assessed the impact of the school curriculum as the most important reason behind religious intolerance, while Ahmadiyya and Christians viewed hate literature as the reason for the case of intolerance (Khan, Österman, \& Björkqvist, 2017).

The fact of the case of intolerance results from the values of characters that have'nt been internalized in human characters. Education has a role in character development through character education. The results showed confidence in students can develop skills and ability to interact positively with the environment and peers (Elias, et.al., 2008; Richardson, Tolson, Huang, \& Lee, 2009). The results also show that teachers as a model to contribute to the moral education of children, thus forming a more caring community, student discipline directions drop significantly, especially in areas associated with bullying behavior, and the value of school-based tests with achievement is on the rise almost 50\%. (Marshall,Caldwell, \& Foster, 2011; Sanderse, 2013). Schools have a common role todevelop students' character. The results show that parents, teachers, and administrators as stakeholders jointly combine to encourage students to embody the values of both life in relation to an inclusive and diverse identity in terms of both format and substance in the process of establishing a national identity that results in affective reinforcement and intellectual attitudes that affect social attitudes, social skills, spiritual attitudes (Parker, Nelson, \& Burns, 2010; Trisiana, 2015; Wang, 2017).

School counselors have a responsibility to instill character values through counseling and guidance services. Professional School Counselors (PSCs) are required to demonstrate how comprehensive development programs support student outcomes (American School Counselor Association (ASCA), 2005; Dahir \& Stone, 2003; Gysbers, 2004; Lapan, 2005; Sciarra, 2004). Group counseling services as a way to shape mutual respect with counseling and guidance functions. The results of the study indicate that the activities or interventions of school counseling programs vary in effectiveness (Whiston, Tai, Rahardja, \& Eder (2011). The folklore method as a method can be used to develop the character of the students through counseling and guidance services. The results show that the story The people of Malang (East Java) "contain the values of character education in the form of faith, the power of a prayer, honesty, discipline, hard work, creativity, independence, curiosity, abstinence, tolerance, appreciation, friendship, 
peace, caring to others, to preserve nature, to utilize nature, and to love the motherland (Malitasari, 2013).

\section{Group-Based Folk Story Guidance}

Group guidance has a different meaning between one expert and another. Romlah (2001) defines group guidance as one of the guidance techniques that seeks to help individuals to achieve their development optimally according to their abilities, talents, interests, and values adopted in group situations. Group guidance is aimed at preventing students from developing problems and developing student potential. Wibowo (2005) states that group guidance is a group activity in which group leaders provide information and direct the discussion so that group members become more social or to assist group members to achieve common goals. Sukardi (2003) Group guidance services are intended to enable students to collectively obtain materials from resource persons (especially tutors) that are useful for daily life both as individuals and as students, family members and communities.

Group guidance services are implemented on a folklore basis. Folklore can be interpreted as a cultural expression of a community through speech language that is directly related to various aspects of the culture and social structure of the society. Folklore has the meaning of a complex of songs, legends, stories that form an oral tradition of unwritten culture (Reber \& Reber, 2010: 370). Folkloreis passed down from one generation to the next by orally (Hutomo, 1991).

The group guidance service consists of five stages. According to Prayitno (2012) the steps in group guidance are (a) the stage of formation; (b) the transitional stage; (c) activity stage; (d) the inference stage; and (e) closing stages. First, the stage of formation is the stage to form a crowd of individuals into a group that is ready to develop group dynamics in achieving common goals. Second, the transitional phase is the stage to divert the group's initial activities to the next activity that is more focused on achieving group goals. Third, the stage ofactivity is the stage of the core activities to discuss certain topics. Fourth, the inference stage is the stage of activity to review what the group has done and achieved. The group participants were asked to reflect on the activities they had just followed. The last, the closing stage is the final stage of all activities.

Conclusion group guidance of folklore-based is one of guidance and counseling service that seeks to help individuals to achieve their development optimally according to their ability, talents, interests, and values adopted in group situations using folk-based media. Folktale is an oral literature that exists in society. Folklore is an inherited heritage passed down through generations through oral and written. The groups guidance of folklore-based uses five stages, namely the stage of formation, transition, activity, inference, and closure.

\section{Method}

This research uses literature study method. This research is to reveal effective theories about the group's guidance services folklore based. The literature study is used to construct the theoretical concepts of folklore methods that can be used in guidance and counseling services, in particular group counseling services. The objective of the research is to establish the theoretical 
concepts and practice of folklore as a medium of group counseling service through past history to foster the National Character. The theoretical concepts of group guidance services with folklore methods can be used by school counselors as one way to build student character.

The data used in the study were sourced from the literature as well as the primary references. The literature and references are valid and used in this research in the form of journals, books, scientific studies and research results. The form of the journal literature, books, scientific studies and research results in the form of text. The instruments used are journal documents, books, and relevant research results. Literature review and reference in content analysis so that emphasize on the analysis or interpretation of written materials based on the context.

The analysis used in descriptive study of literature study in three ways, namely (1) inventory of literature, (2) description of literature, and (3) comparison of literature. The first stage, the literature inventory by collecting literature on appropriate methods for the development of student characters according to the tasks of student development, the process of implementing the group guidance services, the concept of folklore that can be used in the guidance services of the group on the students of Junior High School, and the implementation procedures of group guidance services method of folklore to students of Junior High School. The second stage, the literature description to describe the role of folklore in the implementation of group guidance services by counselors and types of folklore. The last stage, the literature comparison to build theoretical and applicative concepts about the folklore method in the implementation of group guidance services by school counselors.

\section{Findings and Discussion}

The results of this study found facts that of variety primary sources such as scientific journals, books, and research. Scientific journals, books, and research results reveal the concept of group counseling methods in the development of student character, group counseling services implementation procedures, and the role of folklore in the implementation of group counseling services to develop the student's character.

The findings about group guidance service can be implemented through a variety of effective methods. Alhadi, Supriyanto, \& Dina (2016) revealed that media in guidance and counseling services play an important role in the implementation of guidance and counseling so that students can better understand and internalize the material guidance and counseling services. Myrick (2011) revealed that Large group guidance can address character issues through variety methods. Research Sink\& Edwards (2008); Galassi, Griffin, \& Akos (2008); Van Velsor (2009) find fact that professional school counselors are equipped with effective techniques to improve multicultural competence and student strengths in school counseling programs based on prevention and self-repositioning socially and emotionally. Implementation of group guidance services to develop characters requires media tailored to the developmental tasks of junior high school students with the cooperation between counselors and related parties. The media group 
counseling services will lead to great opportunities that are effective for the development of multicultural competencies of students in counseling and guidance programs.

Table 1. Concept of Group Guidance Service for Developing Character

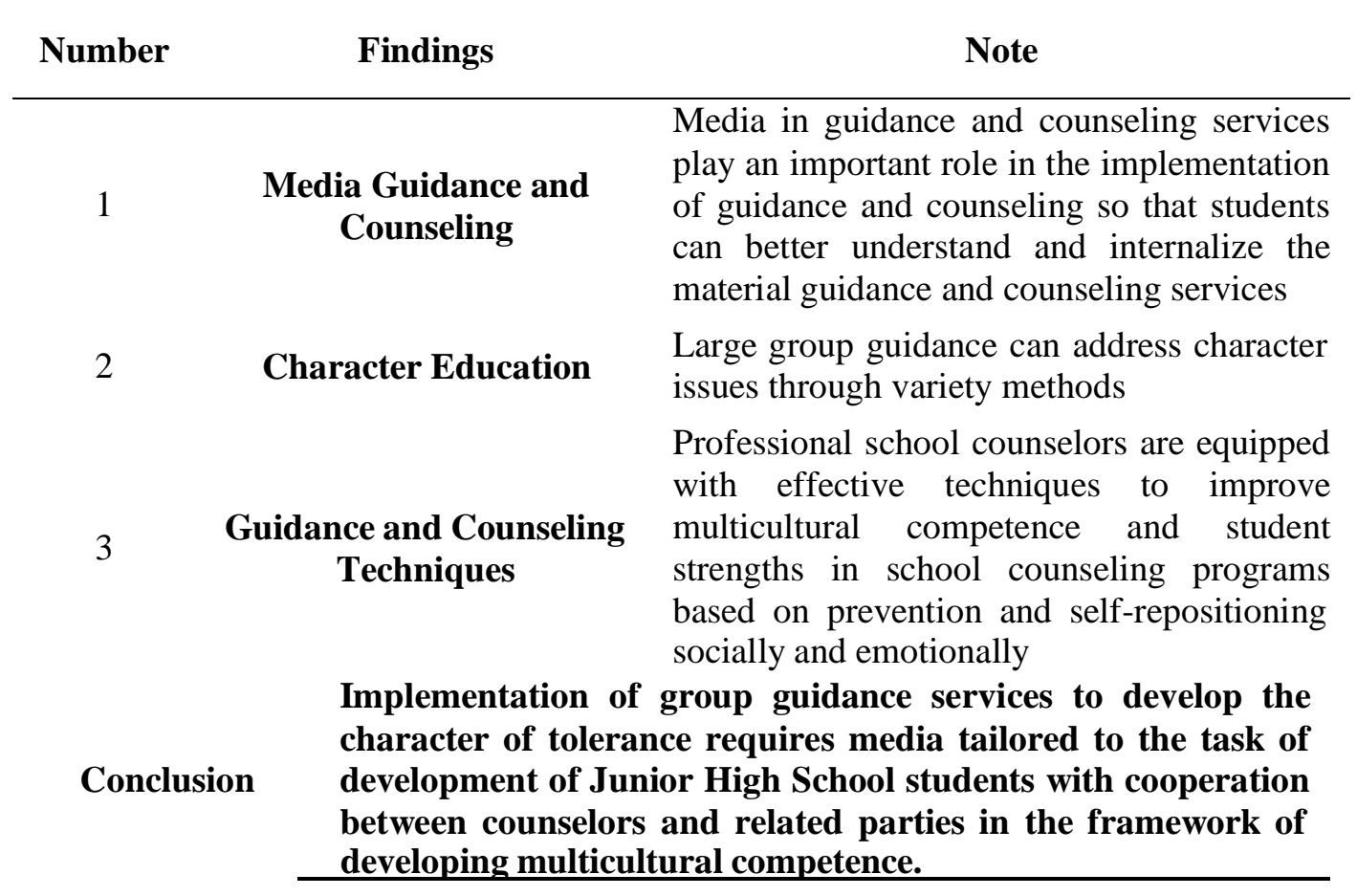

The development of student character in the implementation of group guidance services can use the folklore method. The use of didactic folklore can evoke sensitivity, self-awareness and embrace the noble, pious and humanistnature. (Okeowo \& Okeowo, 2015). This opinion is corroborated by researchfrom Sakiyeva, Berdibayeva, Shomanbayeva, \& Kalkhojayeva (2014), that the components of the internal structure of the individual are ethnic identities as community awareness of membership in certain social and ethnic groups reflecting the nation's situation in the social system. research show that the People's story from Malang (East Java) "contains the values of character education in the form of faith, the power of a prayer, honesty, discipline, hard work, creativity, independence, curiosity, abstinence, tolerance, love of peace, caring for others, nurturing nature, utilizing nature, and love of the country (Malitasari, 2013).

The ability of counselors in the implementation of group guidance services of effective folklore methods in the development of student potential. The results of Hariyadi, Sugiharto \& Sutoyo (2014) revealed that there was an increase in interpersonal intelligence of $13.9 \%$ from medium to high category through group guidance services with biblio-counseling techniques based on folklore. The results of research Purnami, Garminah, \& Sudarma (2014); Widiawati, Suarni, \& Ujianti (2017) revealed that the sociodrama method of folklore has a positive effect on the ability to speak to children compared to groups of students who were taught by 
conventional methods. Research Susilowati (2016); Sundari, Sinaga, Ritonga \& Ekomila (2017) that the Folktale Speaking program can enhance the existence of Nusantara folklore and shape the character of the students through group counseling services in the private social field, and able to cooperate with subject teachers. The result of the Warta (2012) study that folklore not only presents social conflicts but also shows some ways to resolve conflicts and conflicts bringing the attitude to be wise enough to face, as well as folklore can help to develop students into good students morally and humanist. The conclusion of the research results shows the fact that the role of the past in the folklore of a country can foster multicultural competence according to the values of character educationin the social system of the nation.

Table 2. Character Values in Folklore in Group Guidance Services

\begin{tabular}{|c|c|c|}
\hline Number & Findings & Note \\
\hline 1 & Folklore Function & $\begin{array}{l}\text { The folklore of ethnic identity-formers as } \\
\text { public awareness of membership in certain } \\
\text { social and ethnic groups reflects the nation's } \\
\text { situation in the social system, and is able to } \\
\text { arouse sensitivity, self-awareness, embrace } \\
\text { the noble, pious and humanist nature. }\end{array}$ \\
\hline 2 & $\begin{array}{l}\text { Character Education from } \\
\text { folklore }\end{array}$ & $\begin{array}{l}\text { The value of embedded character values } \\
\text { such as faith, the power of a prayer, honesty, } \\
\text { discipline, hard work, creativity, } \\
\text { independence, curiosity, unyielding, } \\
\text { tolerance, respectful achievement, } \\
\text { friendship, peace of mind, caring for others, } \\
\text { nurturing nature, the homeland appears in } \\
\text { the folklore of a nation. }\end{array}$ \\
\hline 3 & $\begin{array}{l}\text { Metode Folklore in the } \\
\text { Implementation of Group } \\
\text { Guidance Services }\end{array}$ & $\begin{array}{l}\text { Folklore positively affects the character } \\
\text { values in the personal social field morally } \\
\text { and humanist and able to cooperate with } \\
\text { subject teachers. }\end{array}$ \\
\hline Conclusior & \multicolumn{2}{|c|}{$\begin{array}{l}\text { The value of folklore character values positively affects the } \\
\text { moral and humanist social person for the formation of ethnic } \\
\text { identity as public awareness of membership in certain social } \\
\text { and ethnic groups reflecting the nation's situation. }\end{array}$} \\
\hline
\end{tabular}

Implementation of group guidance of folklore method according to the implementation procedure. Implementation procedures are applied in accordance with the research of the literature review. Shertzer \& Stone (1980) stages of group counseling, (1) giving students personal information to students, (2) individual discussions challenging activity plans, and (3) students having the option to solve problems, goals, and solutions. Gladding (2009) describes the stages of activities in the group, namely (1) the stage of formation, (2) the exploration stage, (3) the regulatory phase, (4) the implementation stage / work, and (5) the merger / termination stage. Prayitno (2012) preparing steps in group guidance are (a) the stage of formation; (b) the transitional stage; (c) activity stage; (d) the inference 
stage; and (e) closing stages. Activity in group guidance requires effective group skills for the development of student character. Johnson \& Johnson (2006) explains that the group has goals, cooperation, cooperative, productive, communicative, joint decisions with negotiation, commitment to decision, group quality, creativity, leadership and cohesion.

Table 3. Implementation Stage of Group Guidance Services Method of Folklore

\begin{tabular}{|c|c|c|}
\hline Number & Findings & Note \\
\hline 1 & $\begin{array}{l}\text { Procedure Group Guidance } \\
\text { Services of Folklore } \\
\text { Method }\end{array}$ & $\begin{array}{l}\text { (1) the stage of formation; (2) the } \\
\text { transitional stage; (3) activity stage; (4) the } \\
\text { inference stage; and (5) termination stage }\end{array}$ \\
\hline 2 & Group Concepts & $\begin{array}{l}\text { The group has purpose, cooperation, } \\
\text { cooperative, productive, communicative, } \\
\text { joint decision with negotiation, commitment } \\
\text { to decision, group quality, creativity, } \\
\text { leadership and cohesion }\end{array}$ \\
\hline 3 & $\begin{array}{l}\text { Objectives of the Group } \\
\text { Guidance Services }\end{array}$ & $\begin{array}{l}\text { (1) provide students with personal } \\
\text { information on students, (2) personal } \\
\text { discussions about the activity plan, and (3) } \\
\text { students have the option to solve problems, } \\
\text { goals, and solutions. }\end{array}$ \\
\hline
\end{tabular}

Stages of implementation of guidance group of folklore methods through five stages, namely

(1) Establishment stage: provide the foundation for the implementation of group guidance services to group members

(2) Transitional stage: group members can place Conclusion themselves on group hierarchy.

(3) Stage of work: group members led by group leaders are actively and collectively involved, so the group can be productive.

(4) Concluding stages: the group concludes the discussion of the meaning of folklore in personal and social life (5) Termination stage: group ends and say goodbye.

Implementation of group guidance services of folklore methods with five stages, namely (a) stage of formation; (b) the transitional stage; (c) activity stage; (d) termination stage; and (e) closing stages. The guidance services group of folklore methods to cultivate multicultural competence. The value of folklore character values positively affects social personality morally and humanist.

\section{Conclusions}

Implementation of group guidance services to develop the character of tolerance requires media tailored to the task of development of Junior High School students with cooperation between counselors and related parties in the framework of developing multicultural competence. How to develop multicultural 
competence through the role of the past in a nation's folklore according to the values of character education. The value of folklore character values positively affects social personality morally and humanist. Folklore as the formation of ethnic identity as public awareness of membership in certain social and ethnic groups reflecting the nation's situation. Implementation of group guidance services of folklore methods with five stages, namely (a) stage of formation; (b) the transitional stage; (c) activity stage; (d) termination stage; and (e) closing stages. The results of the implementation of the group guidance services of folklore methods as the formation of ethnic identity of the nation have positive influence on the social person morally and humanist or the multicultural competence of the students.

\section{References}

Alhadi, S., Supriyanto, A., \& Dina, D. A. M. (2016). Media in guidance and counseling services: a tool and innovation for school counselor. SCHOULID: Indonesian Journal of School Counseling, 1(1), 6- 11.

Andersen, R., \& Fetner, T. (2008). Economic inequality and intolerance: Attitudes toward homosexuality in 35 democracies. American Journal of Political Science, 52(4), 942-958.

American School Counselor Association. (2005). The ASCA national model: A framework for school counseling programs ( $2^{\text {nd }}$ ed.). California: Alexandria.

Dahir, C. A., \& Stone, C. B. (2003). Accountability: A M.E.A.S.U.R.E. of the impact school counselors have on student achievement. Professional School Counseling, 6, 214-221

Elias, M. J., Parker, S. J., Kash, V. M., Weissberg, R. P., \& O’Brien, M. U. (2008). Social and emotional learning, moral education, and character education: A comparative analysis and a view toward convergence. Handbook of moral and character education, 248-266.

Galassi, J., Griffin, D., \& Akos, P. (2008). Strengths-based school counseling and the ASCA national model ${ }^{\circ}$. Professional School Counseling, 12(2), 176181.

Gladding, S.T. (2009). Counseling: A Comprehensive Profession. New Jersey: Pearson Education, Inc.

Giugni, M., \& Morariu, M. (2010). Intolerance begets intolerance: Explaining negative attitudes towards foreigners and Muslims in Switzerland, 19962007. In Simon Hug and Hanspeter Kriesi, Value change in Switzerland. Lexington Books.

Gysbers, N. (2004). Comprehensive guidance and counseling programs: The evolution of accountability. Professional School Counseling, 8, 1-14.

Hariyadi, S., Sugiharto, D. Y. P., \& Sutoyo, A. (2014). Bimbingan Kelompok Teknik Biblio-Counseling Berbasis Cerita Rakyat untuk Mengembangkan Kecerdasan Intrapersonal Siswa SMP. Jurnal Bimbingan Konseling, 3(2), 97103.

Hutomo, S. S. (1991). Mutiara yang Terlupakan: Pengantar Studi Sastra Lisan. Surabaya: HISKI Jawa Timur. 
Johnson, D. W. \& Johnson, F. P. (2006). Joining Togehter. New Jersey: Pearson Education Inc.

Khan, T., Österman, K., \& Björkqvist, K. (2017). Severity and Reasons Behind Religious Intolerance in Pakistan: Perceptions of Sunnis, Shias, Ahmadis, and Christians. EJSER European Journal of Social Sciences Education and Research Articles, 10(2), 193-202

Lapan, R. T. (2005). Evaluating school counseling programs. In C. Sink, Contemporary school counseling: Theory, research, and practice. Boston: Lahaska Press.

Malitasari, N. (2013). Nilai-nilai Pendidikan Karakter dalam Cerita Rakyat (Skripsi, Universitas Jember).

Myrick, R. D. (2011). Developmental Guidance and Counseling: A Practical Approach (5th ed.). Minneapolis: Educational Media Corporation.

Marshall, J. C., Caldwell, S. D., \& Foster, J. (2011). Moral education the CHARACTER plus Way®. Journal of Moral Education, 40(1), 51-72.

Nurdin, E. S. (2015). The Policies on Civic Education in Developing National Character in Indonesia. International Education Studies, 8(8), 199-209.

Okeowo, A. O., \& Okeowo, A. O. (2015). Applicability of Archetypes and the Folkloric Panacea on Societal Ills and Degradation of Morality. International Conference on Humanities, Literature and Management (ICHLM'15), 161164.

Parker, D. C., Nelson, J. S., \& Burns, M. K. (2010). Comparison of correlates of classroom behavior problems in schools with and without a school-wide character education program. Psychology in the Schools, 47(8), 817-827.

Prayitno. (2012). Jenis Layanan dan Kegiatan Pendukung Konseling. Padang: Universitas Negeri Padang.

Purnami, K. A., Garminah, N. N., Hum, M., \& Sudarma, I. K. (2014). Pengaruh Metode Sosiodrama Berbantuan Cerita Rakyat Terhadap Keterampilan Berbicara Siswa Kelas V. E-Journal MIMBAR PGSD, 2(1).

Reber, A.S., \& Reber, E.S. (2010). The Penguin Dictionary of Psychology. Yogyakarta: Pustaka Pelajar

Richardson, R. C., Tolson, H., Huang, T. Y., \& Lee, Y. H. (2009). Character education: Lessons for teaching social and emotional competence. Children \& Schools, 31(2), 71-78.

Romlah, T. (2001). Teori dan Praktek Bimbingan Kelompok. Malang: UN.

Sakhiyeva, F., Berdibayeva, S., Shomanbayeva, A., \& Kalkhojayeva, A. (2014). Ethnic Identity as an Ethnic Identity Aggregate Value Orientations. Procedia-Social and Behavioral Sciences, 114, 415-419.

Sanderse, W. (2013). The meaning of role modelling in moral and character education. Journal of Moral Education, 42(1), 28-42.

Sciarra, D. T. (2004). School counseling: Foundations and contemporary issues. Belmont, CA: Brook/Cole-Thomas Learning.

Setiawan, D. (2015). Kasus Intoleransi, DI Yogyakarta Diminta Waspada (Ed). regional.kompas.com. 
Sink, C., \& Edwards, C. (2008). Supportive learning communities and the transformative role of professional school counselors. Professional School Counseling, 12(2), 108-114.

Shertzer, B. \& Stone, S. C. (1980). Fundamental of Counseling. Boston: Houghton Miffin Company.

Sukardi, D. K.. (2003). Menejemen Bimbingan dan Konseling di Sekolah. Bandung: Alfabeta.

Sultoni, A., \& Hilmi, H. S. (2015). Pembelajaran Sastra Berbasis Kearifan Lokal Sebagai Upaya Optimalisasi Pendidikan Karakter Kebangsaan Menuju Masyarakat Ekonomi ASEAN (MEA). Proceedings. Seminar Nasional Pendidikan Bahasa Indonesia.

Sundari, F., Sinaga, E., Ritonga, N., \& Ekomila, S. (2017). Penerapan Program Fos (Folktale Speaking) Sebagai Pembentuk Karakter Anak Usia Dini. JUPIIS: Jurnal Pendidikan Ilmu-ilmu Sosial, 9(1), 106-115.

Susilowati, D. (2017). Pengembangan Media Bimbingan Autoplay tentang Karakter Tanggung Jawab Siswa SMP Berbasis Cerita Rakyat. SKRIPSI Jurusan Bimbingan dan Konseling \& Psikologi-Fakultas Ilmu Pendidikan $U M$.

Trisiana, A. (2015). Action for Citizenship Education of Character Education Using Project Citizen Model at Senior High School In Indonesia. International Journal of Education and Psychology in the Community, 5(1/2), 42-53

Van Velsor, P. (2009). School counselors as social-emotional learning consultants: Where do we begin?. Professional School Counseling, 13(1), 50-58.

Wang, L. (2017). What Does It Mean to Be Canadian? Building National Identity for Secondary Students Through History. University of Toronto.

Warta, I. K. W. I. K. (2012). Developing Students'moral Value through Folklore in Mul Folklore In Multilingual Setting. Delhi Business Review 13(1), 1-11.

Widiawati, G. A. K. H., Suarni, N. K., Ujianti, P. R., \& Psi, S. (2017). Pengaruh Metode Sosiodrama Bermuatan Cerita Rakyat Terhadap Kemampuan Berbicara Pada Anak Terhadap Kemampuan Berbicara pada Anak. Jurnal Pendidikan Anak Usia Dini, 5(1).

Whiston, S. C., Tai, W. L., Rahardja, D., \& Eder, K. (2011). School counseling outcome: A meta-analytic examination of interventions. Journal of Counseling \& Development, 89(1), 37-55. 